\title{
Fesyen Wanita Menurut Perspektif Islam dan Kesannya Terhadap Kesejahteraan Fizikal dan Spiritual
}

\author{
Rashidah Othman ${ }^{a}$, Siti Norlina Muhamad ${ }^{\text {** }}$, Farahwahida Mohd Yusof ${ }^{b}$, Muhammad Amir Wan Harun $^{a}$ \\ ${ }^{a}$ Fakulti Tamadun Islam, Universiti Teknologi Malaysia, 81310 UTM Johor Bahru, Johor, Malaysia \\ ${ }^{b}$ Pusat Penyelidikan Figh Sains dan Teknologi (CFiRST), Universiti Teknologi Malaysia, 81310 UTM Johor Bahru, Johor, Malaysia
}

*Corresponding author: norlina@utm.my

\begin{abstract}
Fashion is the popular or the latest style of clothing or behaviour that evolves with time. Fashion may influence the way of living of the society. The current fashion scene presents to the general public an abundance of fashion trends. However, most of them tend to accentuate the figure of the wearer which does not meet the concept of covering aurah properly, with designs that are see-through or close-fitting. This matter must be taken into consideration since covering the aurah is compulsory in the Islamic Law. This article, therefore, discusses women fashion according to the Islamic perspective and its impact on their physical and spiritual health. From the physical aspect, dressing according to the Islamic way can balance the stimulation of the hormone and mind. In addition to regulating the body temperature through the head, it coordinates the balance between a healthy body and good brain functioning. It also aids in the development of a great intellect and motivation, and it encourages the development of positive behaviour. Meanwhile, from the spiritual aspect, it deepens their faith and piety to Allah, as well as gives high confidence and self-esteem in the women. It also preserves their dignity and honour. Hence, the fundamentals of the fashion design that is based on the Islamic way of dressing are beneficial in attaining the blessings from Allah and maintaining a good health.
\end{abstract}

Keywords: Women fashion, Islamic, health, physical, spiritual, effect

\section{Abstrak}

Fesyen adalah gaya berpakaian, tingkah laku yang menjadi kegemaran serta ikutan ramai dan berubah mengikut peredaran masa. Ia boleh mempengaruhi gaya hidup dalam kehidupan masyarakat. Fenomena fesyen masa kini memperlihatkan kepada masyarakat dengan kepelbagaian trend fesyen. Walau bagaimanapun, trend fesyen tersebut menonjolkan reka bentuk pakaian yang kurang menepati konsep menutup aurat yang sempurna dengan reka bentuk pakaian yang nipis sehingga menampakkan bentuk tubuh badan, ketat dan sebagainya. Perkara ini harus diambil kira kerana menutup aurat adalah tuntutan syariat Islam. Oleh itu, artikel ini membincangkan fesyen wanita menurut perspektif Islam serta kesannya terhadap kesihatan fizikal dan spiritual. Dari aspek fizikal, ia memberi keseimbangan rangsangan hormon secara sihat. Ia juga dapat mengawal keseimbangan rangsangan otak. Disamping itu, ia menggalakkan perkembangan tingkah laku yang baik. Selain itu, ia juga dapat mengawal keseimbangan kepanasan badan melalui kepala. Seterusnya ia membantu dalam keseimbangan badan secara sihat dan fungsi otak dengan baik. Ia juga membantu dalam menggalakkan prestasi intelektual dan motivasi yang sihat. Dari aspek spiritual pula, ia dapat meningkatkan keimanan dan ketakwaan kepada Allah serta keyakinan atau self-esteem wanita yang tinggi. Ia juga dapat memelihara digniti atau maruah wanita. Oleh itu, asas dalam rekabentuk fesyen berteraskan ciri pakaian Islam mempunyai keistimewaan dapat memperoleh keredhoan Allah S.W.T dan kesejahteraan kesihatan wanita.

Kata kunci: Fesyen wanita, Islam, kesihatan, fizikal, spiritual, kesan

(C) 2016 Penerbit UTM Press. All rights reserved

\subsection{PENGENALAN}

Menutup aurat adalah fitrah semula jadi manusia dan merupakan suatu kewajipan bagi wanita. Ia telah disyariatkan Allah untuk memelihara aurat dan perhiasannya daripada diperlihatkan kepada masyarakat. Sehubungan itu, Islam meletakkan panduan fesyen pakaian kepada wanita demi merealisasikan tuntutan syariat dalam menutup aurat yang sempurna. Senario perkembangan fesyen wanita kontemporari hari ini memperlihatkan kepentingan fesyen daripada tuntutan agama pada pemakaiannya. Fenomena ini dapat dilihat dalam pertunjukan fesyen di Malaysia antaranya 'Islamic Fashion Festival'. Konsep pakaian yang ditonjolkan tidak melambangkan konsep Islam sepenuhnya. Malah ia cuba mengislamisasikan konsep fesyen barat. Malah ia diterima sebagai fesyen berlandaskan syariat Islam. Islam tidak melarang wanita berfesyen atau memakai pakaian yang cantik dengan kepelbagaian reka bentuk. Islam mengharuskan bagi wanita berfesyen [1]. Kerana ia merupakan fitrah wanita yang sukakan kecantikan. Rasulullah SAW juga menegaskan bahawa: Allah SWT itu indah, Dia cintakan keindahan [2] [Muslim, 1998:275]. Oleh itu, tidak salah bagi wanita ingin memilih dan memakai pakaian yang berfesyen, tetapi ia mesti mengikut garis panduan yang ditetapkan oleh Islam. 


\subsection{KONSEP FESYEN WANITA MENURUT PERSPEKTIF ISLAM}

Islam meletakkan garis panduan bagi fesyen wanita merangkumi aspek reka bentuk pakaian, jenis pakaian dan aksesori.

\subsection{Reka Bentuk Pakaian}

Konsep reka bentuk pakaian wanita menurut perspektif Islam dapat dikelaskan sebagaimana berikut [3], [4]:

i. Pakaian mestilah menutupi seluruh tubuh badan wanita kecuali anggota yang terdapat pengecualian seperti muka dan tangan. Kebanyakan pereka fesyen kontemporari memandang remeh konsep ini, memandangkan ia adalah trend yang sentiasa mengikuti pasaran dunia fesyen terkini. Ia dapat dilihat pada pola reka bentuk yang mengalami perubahan. Meskipun begitu terdapat sebilangan kecil fesyen yang mengekalkan fesyen mengikut syariat Islam. Allah S.W.T menegaskan tentang kewajipan wanita menutupi segala perhiasannya daripada pandangan golongan ajnabi. Allah S.W.T berfirman yang bermaksud; Dan katakanlah kepada perempuan-perempuan yang beriman itu supaya menyekat pandangan mereka (daripada yang diharamkan) dan memelihara kehormatan mereka; dan janganlah mereka menzahirkan perhiasan tubuh mereka kecuali yang zahir daripadanya; dan hendaklah mereka menutup belahan leher bajunya dengan tudung kepala mereka [Surah al-Nur: 31]. Menurut Ibnu Kathir (1999)maksud "kecuali yang zahir daripadanya" adalah kain yang dipakai di atas baju atau pakaian. Pandangan yang rajih dalam konteks ini menurut riwayat Ibn Abbas, harus bagi wanita menampakkan muka dan kedua tangannya dan wajib menutup aurat kecuali selain bahagian tersebut [6]. Abdul Kareem Zaidan (2000)[3] menambah, harus bagi wanita menampakkan muka, kedua tangan dan kaki.

Oleh itu, wajib bagi wanita menutup keseluruhan tubuh badannya melainkan muka, kedua tangannya berdasarkan riwayat yang sahih. Hal ini sesuai dengan keadaan dan budaya wanita zaman sekarang yang kebanyakannya bekerjaya. Apabila mewajibkan menutup muka dan tangan boleh merumitkan lagi keadaan wanita di tempat kerja dan sebagai seorang wanita yang bekerjaya.

ii. Pakaian itu mestilah tebal, tidak terlalu nipis dan selesa dipakai

Kewajipan menutup aurat adalah amat dititik beratkan dalam Islam. Ia bukan sekadar mengutamakan fesyen tetapi tuntutan syariat Islam lebih penting. Oleh itu, Islam telah memberi panduan pakaian pada wanita mestilah memakai pakaian yang tebal dan tidak terlalu nipis kerana ia boleh menimbulkan pelbagai fitnah. Ia juga dapat menjaga kehormatan wanita daripada mempamerkan kecantikan tubuh badannya di khalayak umum.

Dalil al-Quran dan al-Hadith amat jelas menyatakan bahawa Islam mengharamkan perempuan memakai pakaian yang nipis sehingga menampakkan kulitnya. Diantaranya pakaian yang dapat menampakkan bahagian-bahagian tubuh, khususnya tempattempat yang membawa fitnah, seperti: bahagian dada, paha, dan sebagainya. Rasulullah s.a.w. bersabda:

"Ada dua golongan dari ahli neraka yang belum pernah saya lihat keduanya itu: (l) Kaum yang membawa cambuk seperti ekor sapi yang mereka pakai buat memukul orang (penguasa yang kejam); (2) Perempuan-perempuan yang berpakaian tetapi telanjang, yang cenderung kepada perbuatan maksiat dan mencenderungkan orang lain kepada perbuatan maksiat, rambutnya sebesar punuk unta. Mereka ini tidak akan boleh masuk syurga, serta tidak dapat mencium bau syurga, padahal bau syurga itu tercium sejauh perjalanan demikian dan demikian. [Muslim, 1998: 2128]

Menurut Imam Suyuti maksud "perempuan yang berpakaian tetapi telanjang" dalam hadis tersebut ialah perempuan yang memakai pakaian yang nipis dan menampakkan bayangan auratnya [7]. Selain itu, Ibn Taimiyyah (2005)[8] menjelaskan bahawa perempuan tersebut memakai pakaian menutupi badannya tetapi pada hakikatnya tidak berpakaian. Hal tersebut seperti perempuan yang memakai pakaian yang nipis menampakkan warna kulitnya, atau memakai pakaian yang ketat menampakkan bentuk tubuh badannya. Terdapat hadis lain yang menjelaskan larangan memakai pakaian nipis iaitu;

Saidatina Aisyah r.a meriwayatkan, saudaranya iaitu Asma' binti Abu Bakar pernah masuk di rumah Nabi dengan berpakaian jarang sehingga nampak kulitnya. Kemudian baginda SAW berpaling dan mengatakan: "Hai Asma'! Sesungguhnya seorang perempuan apabila sudah haid (cukup umurnya), tidak patut diperlihatkan tubuhnya itu, melainkan ini dan ini -- sambil ia menunjuk muka dan dua tapak tangannya." [9] (Abu Daud, 2003: 4106)].

\section{iii. Pakaian itu longgar dan tidak terlalu sempit}

Allah S.W.T mensyariatkan wanita menutup aurat kerana hikmah tersendiri. Ia bagi menghindarkan daripada fitnah, kemungkaran yang berleluasa dalam masyarakat. Allah SWT melarang wanita mempamerkan badannya atau bahagian-bahagian daipadanya kepada golongan ajnabi. Mendedahkan tubuh badan sama ada dengan berpakaian nipis, sempit adalah haram boleh menimbulkan nafsu syahwat dan fitnah. Ia juga tidak memenuhi tujuan sebenar pensyariatan pakaian menurut Islam. Oleh itu, disyaratkan bagi wanita muslimah memakai pakaian yang besar dan longgar untuk mengelakkan fitnah, kemungkaran dan menarik pandangan nafsu syahwat [4].

Terdapat hadis yang melarang memakai pakaian yang boleh menampakkan bentuk tubuh dan warna kulit. Hadis Usamah bin Zaid: Rasulullah S.A.W memakaikan dia baju Qibti (baju yang disandarkan pada nama tempat di Mesir) yang tebal, ia pernah dihadiahkan kepada Dihyah al-Kalbi, maka diberi kepada isterinya, kemudian Rasulullah bertanya: kenapa dia tidak memakai baju (Qibtiah) tersebut?, lalu dia menjawab, ia telah diberi kepada isteri. Kemudian Rasulullah bersabda: suruhlah isteri kamu lapik di atas kainnya kerana dikhuatiri menampakkan bentuk tubuh badannya [10] (Ahmad bin Hanbal, 2001: 21834)] 


\subsection{Jenis Pakaian}

Jenis pakaian wanita muslimah menurut Islam adalah tidak memakai pakaian yang menyerupai lelaki dan tidak menyerupai pakaian wanita kafir. Di samping itu, pakaian tersebut bukan bermaksud untuk tujuan kemasyhuran [4], [1].

i. $\quad$ Pakaian tersebut tidak menyerupai pakaian lelaki.

Allah S.W.T telah mencipta lelaki dan perempuan dengan fitrah masing-masing yang sempurna dan sesuai. Senario fesyen moden yang berkembang pesat dalam kalangan wanita dan lelaki memberi kesan terhadap gaya hidup. Pemakaian pakaian t-shirt bagi wanita menyerupai lelaki dan seluar wanita menyerupai seluar lelaki. Realiti pakaian hari ini telah mengubah fitrah Ilahi yang membezakan di antara wanita dan lelaki. Walaubagaimanapun diharuskan bagi wanita memakai t-shirt yang labuh dan seluar yang longgar. Allah S.W.T mengharamkan lelaki menyerupai perempuan, atau perempuan menyerupai lelaki secara umum dan Rasullullah S.W.T melaknat lelaki yang memakai pakaian wanita, dan wanita memakai pakaian lelaki [9] (Abu Daud, 2003: 4100)]. Ia boleh merosakkan fitrah semulajadi ciptaan Allah S.W.T.

\section{ii. Pakaian itu tidak menyerupai pakaian wanita kafir}

Asas dalam syariat Islam adalah menjauhi daripada menyerupai orang kafir iaitu Yahudi, Nasrani dan sebagainya. Ia termasuklah dalam soal ibadah, adat, pakaian dan etika dalam kehidupan. Hal ini berlaku terhadap perkembangan fesyen dalam era globalisasi. Fesyen tersebut dipengaruhi dengan budaya dan pemikiran Barat, dari aspek reka bentuk pakaian yang ditonjolkan terdiri daripada pakaian yang nipis, jarang dan ketat sehingga menampakkan bentuk badan.

Oleh hal demikian, Islam melarang pemakaian sedemikian sebagai mana diriwayatkan oleh Ibnu Umar r.a: "Barang siapa menyerupai satu kaum, maka dia termasuk dalam golongan tersebut" [2] [Abu Daud, 2003: 4033]. Hal demikian dapat dilihat kebanyakan reka bentuk fesyen moden mempengaruhi secara perlahan-lahan cara berpakaian dan berpenampilan umat Islam sehinggakan sama sekali tidak mempunyai ciri keislamannya [2] (Muslim, 1998: 5555)], [11] (Tobroni, 1994: 30909)]. Demikianlah, Islam memiliki keperibadian mulia yang dizahirkan dalam diri manusia sekaligus mengatur kehidupan yang lebih harmoni sesuai dengan fitrah manusia.

Di samping itu, dalam soal memakai pakaian menyerupai orang kafir seperti pakaian khas untuk ibadat, jelas dilarang seperti pakaian berwarna merah yang dipakai oleh paderi Buddha atau tudung wanita seperti tudung yang dipakai oleh paderi wanita (Abdul Kareem Zaidan, 2000)]. Senario pada hari ini, pakaian yang menjadi kebiasaan bagi orang kafir dan dapat diterima dalam kalangan masyarakat Islam seperti 'jaket', 'tali leher', 'seluar jeans', 'blouse' dan sebagainya. Pakaian tersebut tidak dilarang memakainya kerana sudah lama diterima oleh masyarakat sebagai pakaian umum. Pakaian yang dilarang adalah pakaian yang berbetuk keagamaan meraka.

\section{iii. Pakaian itu bukan bermaksud untuk tujuan kemasyhuran}

Pakaian kemasyhuran mempunyai beberapa pengertian menurut pandangan Islam. Sarjana Islam mengklasifikasikan konsep "syuhrah" kepada beberapa kategori. Menurut al-Syaukani (1900)[12] pakaian yang mempunyai gabungan kepelbagaian warna yang keterlaluan berbanding pakaian yang mempunyai satu warna sahaja. Kemudian, ia juga dikategorikan dari aspek material pembuatan pakaian seperti sutera, benang emas atau perak [13]. Abdul Kareem Zaidan (1993)[1] pula menjelaskan ia dikenali dengan pakaian yang mempunyai harga yang mahal. Akhir sekali pakaian yang di pakai untuk menarik perhatian orang [12].

\subsection{Aksesori pada Pakaian}

Aksesori pakaian adalah antara penyeri sesuatu penampilan secara keseluruhannya. Pemilihan aksesori boleh mempengaruhi personaliti yang berbeza pada diri seorang wanita. Ia bukanlah suatu kesalahan. Pemakaian aksesori atau perhiasan pada pakaian haruslah bersederhana mengikut panduan Islam. Islam adalah agama fitrah. Pensyariatan perlaksanaan sesuatu hukum adalah tidak bercanggah dan sesuai dengan fitrah semula jadi manusia. Perhiasan dengan pelbagai bentuk adalah harus pada asalnya, melainkan terdapat dalil yang menegahnya (Abdul Kareem Zaidan, 1993: 347).

Islam meraikan fitrah wanita yang suka kepada kecantikan. Aksesori fesyen wanita kontemporari adalah berbeza mengikut perkembangan semasa dunia fesyen. Dalam konteks aksesori pakaian, ia boleh dikategorikan kepada aspek warna, aksesori pada pakaian seperti manik-manik "beading" dan memakai wangi-wangian.

\section{i. Warna}

Pemakaian pakaian yang berwarna di haruskan bagi lelaki mahupun wanita, melainkan terdapat dalil yg melarangnya. Tidak terbatas dengan kepelbagaian pemilihan warna. Hal ini tidak dilarang oleh nabi s.a.w seperti mana dalam hadis yang menceritakan bahawa Rifa'ah memakai tudung berwarna hijau tetapi Nabi S.A.W tidak melarangnya (al-Bukhari, 2002: 5377)]. Selain itu, Rasulullah S.A.W pernah memakai baju berwarna kuning kekuningan (al-Bukhari, 2002: 166)] [14]. Jelas di sini pemilihan pemakaian yang berwarna adalah diharuskan dalam Islam baik lelaki mahu pun wanita. Namun begitu, ia tidak digalakkan dengan pemilihan warna yang agak keterlaluan sebaliknya bersederhana [1].

\section{ii. Pemakaian bau wangi-wangian}

Ia bermaksud sesuatu benda yang mempunyai bauan yang baik, yang boleh dicium. Ia digunakan oleh manusia untuk menyapu rambut, badan, dan muka seperti kasturi 'misk' [1]. Pada zaman sekarang ia lebih dikenali sebagai perfume, bedak, dan 
deodorant. Secara umumya harus bagi wanita memakai wangi-wangian disandarkan melalui hadis Nabi S.A.W bahawa terdapat seorang wanita yang membuat cincinnya daripada misk, dan Nabi S.A.W mengatakan ia adalah sebaik-baik wangian (al-Nasai', 1986: 1905)] [15]. Hal demikian menunjukkan harus memakai wangi-wangian bagi wanita berdasarkan umum hadis. Kemudian terdapat juga hadis yang lebih khusus melarang wanita memakai wangi-wangian ketika keluar dari rumah iaitu; Nabi S.A.W melarang memakai bau-bauan adalah seumpama berzina kerana memakai bau-bauan bertujuan supaya orang lain dapat menghidu baunnya (Abu Daud, 2003: 4175)] [9]. Apabila wanita memakai bau-bauan dan setiap pandangan ajnabi yang melihatnya adalah zina. Ia boleh merangsang syahwat lelaki terhadap bau-baunnya dan dianggap berdosa (al-Tirmizi, 1997: 2786)] [16].

Wanita diharuskan memakai wangi-wangian jika ia tidak dapat dihidu orang lain. Tetapi kebanyakan 'perfume' pada zaman sekarang, ia dihasilkan seolah-olah untuk menarik perhatian orang dengan pelbagai bau yang menarik sama ada daripada jenis bau yang lembut dan kuat. Jadi, pemakaian yang sebaiknya adalah sekadar membersihkan diri daripada bau yang tidak disenangi supaya tidak menimbulkan fitnah.

\section{iii. Aksesori pakaian mempunyai perhiasan batu permata dan manik-manik}

Kebanyakan reka bentuk fesyen kontemporari wanita sarat dengan pelbagai perhiasan manik-manik, batu permata. Pemakaian perhiasan sedemikian tidak dilarang jika bersifat sederhana. Hal demikian bertepatan dengan konsep tabarruj yang dilarang dalam Islam. Ia adalah mempamerkan kecantikan seluruh badan, pakaian dan perhiasan yang dipakai di hadapan khalayak ramai [33]. Pada dasarnya pensyariatan pakaian dalam Islam adalah menutup aurat, bukan untuk mempamerkan kecantikan [13].

Fenomena dunia fesyen hari ini menggambarkan bahawa pereka fesyen ingin mengekalkan konsep fesyen mengikut syariat Islam, dan dalam masa yang sama mengikut trend masa kini. Oleh hal yang demikian, mereka menghasilkan konsep yang dinamakan fesyen muslimah kontemporari yang dihiasi dengan perhiasan yang menarik. Islam meraikan fitrah manusia yang sukakan kepada kecantikan dan perhiasan, tetapi perlu diingat ia tidak bercanggah dengan ajaran Islam.

\subsection{KESAN MENUTUP AURAT TERHADAP KESIHATAN FIZIKAL DAN SPIRITUAL}

Menutup aurat adalah suatu kewajipan bagi wanita, ia mempunyai pengertian dan hikmah tersirat terhadap fizikal dan spiritual terutama meningkatkan tahap kesihatan wanita. Kajian sains moden [34] [35] [36] [37] mendedahkan bahawa kewajipan menutup aurat bukan hanya suatu amalan kerohanian yang mendekatkan hamba dengan pencipta-Nya. Keistimewaan kewajipan ini ternyata memanfaatkan tubuh manusia terhadap fizikal dan spiritual.

\subsection{Aspek Fizikal}

Fizikal wanita mempunyai kecantikan termasuklah bentuk badan dan paras rupa. Cara pemakaian boleh mengukur kecantikan wanita. sehubungan dengan itu, apabila wanita berpakaian mendedahkan auratnya, ia adalah pendorong kepada lelaki tidak dapat mengawal nafsu [17]. Antara faktor wanita menjadi mangsa dalam kes rogol adalah disebabkan oleh memakai pakaian yang mendedahkan auratnya. Dalam hal ini, lelaki pula mempunyai kelemahannya yang tidak dapat mengawal nafsu [18]. Oleh itu, pakaian seksi melambangkan keperibadian wanita tidak bermoral kerana ia mempamerkan keaibannya dengan berpakaian demikian [19]. Oleh itu, Islam mewajibkan wanita menyembunyikan kecantikannya demi memelihara kesuciannya dan menundukkan pandangan lelaki daripada melihatnya. Dengan itu, masalah seksual dapat dikawal dengan baik dalam kalangan wanita.

\section{a. Memberi keseimbangan rangsangan hormon secara sihat}

Menurut Grammer et al. (2004) pemilihan pakaian wanita yang menampakkan bentuk tubuh, jarang dan ketat dapat memberi ransangan yang positif pada hormon dan menggalakkan motivasi seksual lelaki. Ia saling berhubungkait secara positif antara motivasi seksual lelaki dan tahap hormon testosterone pada pendedahan badan wanita. Oleh itu, tidak mustahil dengan cara pemakaian wanita begini boleh menyumbang kepada berlakunya jenayah seksual, penzinaan dan kes rogol. Islam melarang wanita memperagakan fesyen yang tidak mempamerkan akhlak Islam dalam pemakaiannya seperti yang digambarkan oleh Rasulullah S.A.W fesyen yang berpakaian tetapi telanjang, yang cenderung kepada perbuatan maksiat dan mendorong orang lain kepada perbuatan maksiat.

\section{b. Mengawal keseimbangan rangsangan otak}

Selain itu, Abdullah (2009)[21] mendapati bahawa otak lelaki bertindak balas terhadap pakaian yang tidak menutup badan sepenuhnya. Kajian dijalankan ke atas tarikan seksual jantina berbeza (heterosexual) melalui ujian Magnetic Resonance Imaging (MRI). Kajian ini melihat rangsangan otak terhadap dua keadaan pemakaian wanita; wanita yang memakai pakaian menutup badan sepenuhnya dan tidak memakai pakaian yang sepenuhnya. Ransangan bahagian otak lelaki (premotor cortex) dan (posterior middle temporal gyrus) memberi rangsangan yang jelas iaitu lagi kurang pemakaian pakaian, bahagian otak tersebut akan memberi isyarat. Kemudian bertindak balas kepada wanita tersebut dan melakukan tindakan. Ini adalah bahagian otak yang berkaitan dengan penggunaan alat, manipulasi tangan, dan keinginan untuk mengambil tindakan.

Oleh yang demikian pemakaian yang bersifat sederhana dianjurkan Islam kepada wanita adalah melindungi wanita daripada perasaan seksual di kalangan lelaki. Ia juga adalah suatu batasan yang boleh menghalang daripada tidak menghormati wanita untuk mendekati dalam keadaan yang tidak wajar dilakukan. Jadi, jelaslah pemakaian yang mengikut syara' atau Islam fesyen yang terbaik melindungi wanita dan menjamin keselamatan fizikal dan spiritual wanita. 


\section{c. Menggalakkan perkembangan tingkah laku yang sihat}

Pakaian mengikut syariat Islam dapat mengukuhkan keyakinan diri wanita "self esteem". Ia penting dalam psikologi manusia untuk meneruskan kehidupan yang baik. Ia adalah kemampuan untuk membentuk suatu identiti yang mempunyai nilai [22]. Oleh itu, Allah S.W.T telah menjelaskan bahawa sebaik-baik pakaian bagi wanita adalah pakaian taqwa. Menurut Tobari [23] konsep pakaian ini merangkumi ciri-ciri iman, amal, malu, takut pada Allah SWT dan berkeperibadian yang baik. Jadi ia dapat menjauhkan wanita daripada melakukan maksiat. Dengan itu, wanita sentiasa berada dalam keadaan selamat apabila keluar dari rumah dengan menjaga pemakaiannya mengikut syariat Islam. Ia tidak bertujuan untuk meraih tarikan lelaki, malah tidak memberi peluang tarikan orang melihat kecantikan wanita. Oleh itu, jelaslah pakaian menurut syariat Islam dapat memelihara spiritual yang sihat dalam kalangan wanita.

\section{d. Mengawal keseimbangan kepanasan badan melalui kepala}

Menurut Burns (2000) pemakaian tudung mempunyai kebaikan kepada kesihatan dan suatu pakaian yang terbaik bagi wanita. Menurut beliau, pemakaian tudung sangat penting untuk melindungi kepala. Kajian perubatan menunjukkan bahawa 40-60\% kepanasan badan boleh hilang melalui kepala. Jadi seseorang individu yang menutupi kepala mereka pada bulan sejuk dapat melindungi kepalanya 50\% lebih daripada mereka yang tidak memakainya.

\section{e. Membantu dalam keseimbangan badan (body equilibrium)}

Menurut buku perubatan masyarakat China Hua Di Nei (The Yellow Emperor's Classic on Internal Medicine) menyatakan bahawa pemakaian penutup kepala boleh mengelakkan perubahan suhu pada badan berlaku secara tiba-tiba, bergoyang, lemah dan pergerakan lain yang boleh mengganggu keseimbangan badan (body's equilibrium). Ia boleh menyebabkan kesihatan yang tidak baik. Ia juga boleh mengelakkan daripada selsema, bersin yang berlaku akibat kesejukan [24].

\section{f. Mengawal fungsi otak dengan baik}

Pemakaian tudung penting juga ketika cuaca panas. Menurut V.G. Rocine terkenal sebagai seorang pakar bahagian otak telah menemui bahawa 'brain phosphorus' elemen kimia dalam otak cair pada suhu 108 darjah; suhu ini mudah dicapai apabila seseorang di bawah matahari panas dalam tempoh jangka masa yang lama tanpa menutup kepala. Jadi, apabila keadaan ini berlaku otak mengalami kerosakan, kehilangan memori dan kehilangan sebahagian fungsi pada otak. Walaubagaimanapun, kerosakan bahagian otak masih boleh ditentukan mengikut tahap samada kerap terdedah dengan panas dan terlalu panas kepala [38]. Menurut Bernard Jensen seorang naturopath dan chiropractor, menyatakan bahawa otak kehilangan mineral phosphorus disebabkan oleh kepanasan [39].

\section{g. Membantu dalam menggalakkan prestasi intelektual dan motivasi yang baik}

Dalam aspek pemilihan warna boleh memberi kesan terhadap tingkah laku manusia. Islam tidak melarang wanita memakai pakaian berwarna [1]. Pemilihan warna yang sederhana tidak terlalu menarik perhatian orang lebih mendamaikan pandangan dan jiwa. Ia terbukti warna boleh memberi kesan kepada proses kognitif dan tingkah laku manusia, sebagai contoh warna merah. Ia memberi kesan dalam keadaan tanpa sedar dan niat melihat warna tersebut. Ia juga boleh menjejaskan prestasi intelektual dan mengurangkan motivasi pada individu [25]. Namun menurut Ravi Mehta (2009: 1226)[26] terdapat kajian keatas kesan warna lembut seperti warna biru dan hijau. Ia menggalakkan kepada prestasi yang baik kepada mental proses. Ia juga boleh meningkatkan tindakan proses mental yang lebih kreatif berbanding warna merah. Di samping itu, warna merah juga boleh mengundang lelaki melihat wanita sebagai seorang yang sangat menarik perhatiannya dan mempunyai perasaan seksual terhadap wanita [27].

\subsection{Aspek Spiritual}

Kesihatan adalah suatu keadaan yang sempurna. Ia adalah kualiti hidup yang melibatkan aspek sosial, emosi mental, spiritual dan kecerdasan biological seseorang. Keseimbangan dinamik (dynamic equilibrium) kesihatan seseorang dapat dicapai hasil daripada adaptasi aspek tersebut terhadap persekitaran bagi memperoleh kesihatan yang optimum [28].

Aspek spiritual memainkan peranan yang penting dalam kehidupan manusia. Sehubungan dengan itu, pakaian yang ditonjolkan Islam memberi kesejahteraan dari aspek fizikal mahupun spiritual. Spiritual juga dikenali sebagai rohani. Menurut Al-Ghazali [29] konsep kerohanian ini merujuk kepada empat elemen kerohanian manusia iaitu roh (al-ruh), hati (al-qalb), akal (al- 'aql) dan Nafsu (al-nafs). Ia berkaitan dengan konsep ma'nawi di dalam diri manusia. Aspek ini tidak dapat dipisahkan dan diabaikan dalam tuntutan menutup aurat bagi menjamin kebergantungannya dengan Allah S.W.T dalam usaha mencapai kesejahteraan dalam kehidupan. Aspek kerohanian mampu menyumbang kepada keperibadian yang tinggi. Ia berkait rapat dengan aspek psikologi dan mental manusia dalam konteks kebergantungan manusia kepada Allah S.W.T. Persediaan kerohanian termasuklah sentiasa beriltizam untuk tidak melakukan perbuatan yang dilarang dan melakukan suruhan Nya [30].

Sehubungan dengan itu, pakaian Islam menjamin kehormatan dan kesucian tidak dicemari dengan gangguan seksual. Berpakaian menurut Islam adalah pakaian iman yang memelihara dan membentuk keperibadian berakhlak baik. Ternyata perintah menutup aurat adalah suatu cara terbaik bagi wanita bagi menghindari daripada diganggu dan disakiti [31]. Malah, menutup aurat dapat menzahirkan perasaan malu dalam diri manusia. Perasaan malu ini dapat mencegah daripada perlakuan perbuatan yang tidak baik dan tidak berakhlak [32]. Islam suatu agama indah menekankan sifat malu dalam diri setiap individu samada lelaki mahupun perempuan. Namun begitu, wanita lebih dititkberatkan menjaga maruah kerana mampu menyumbang kepada kemungkaran jika tidak dibendung [40]. 
Menurut Ibrahim, pensyariatan menutup aurat meningkatkan keyakinan diri "self esteem" yang tinggi dan teguh, kerana menjadikan Allah S.W.T. sebagai matlamat utama. Jadi, manusia sentiasa berada dalam keadaan selamat apabila keluar dari rumah. Hal demikian kerana tidak bertujuan untuk meraih tarikan masyarakat, malah tidak memberi peluang tarikan orang melihat kecantikannya. Namun begitu, berpakaian tidak menutup aurat melambangkan peribadi yang tidak bermoral kerana melibatkan diri dalam seks dan (being naked) tidak berpakaian. Seterusnya, mendedahkan tubuh badan yang kebiasaannya di tutup. Bagi keadaan wanita berpakaian yang ketat dan menampakkan bentuk (contuors) tubuh badan adalah seperti tidak berpakaian (naked), kerana menzahirkan dan menonjolkan bahagian badan untuk tarikan perhatian terhadap mereka, samada ia adalah sesuatu perkara yang negatif atau positif, yang penting mendapat perhatian masyarakat [41]. Jadi keadaan ini berlaku di mana seseorang individu mempunyai (low self-esteem) keyakinan diri yang rendah. Ia berada dalam (insecure) tidak terjamin keselamatan pada dirinya [42].

Islam merupakan undang-undang yang mengatur dan memandu kehidupan harian manusia. Lantaran itu, ketaatan merupakan suatu kewajipan terhadap urusan manusia, baik di dunia mahupun akhirat. Setiap perintah yang diberi Allah SWT terhadap hamba-Nya sebgai tanda rahmat dan kasih sayang-Nya, disamping terdapat kebaikan serta hikmahnya. Jika tidak diambil perhatian, maka boleh menyebabkan kerosakan dalam masyarakat. Jelaslah bahawa kebaikan menutup aurat adalah suatu fitrah semula jadi yang sihat. Ia dapat ditonjolkan pada ketaatan seorang hamba kepada penciptanya. Hubungan ini dapat membangunkan serta mendidik jiwa sebagai seorang hamba dan khalifah serta kepentingan al-Qur'an sebagai sumber petunjuk. Hal demikian, memandu manusia menggunakan akal atau nafsu secara positif ke arah pengurusan yang betul dan diredhoi Allah SWT [43].

\subsection{KESIMPULAN}

Fesyen menurut perspektif Islam adalah yang terbaik bagi wanita. Pensyariatannya sesuai dengan fitrah semula jadi wanita. Islam membenarkan wanita berfesyen, malah menyediakan panduan yang terbaik dapat memberi jaminan pada kesihatan fizikal dan spiritual wanita. Oleh itu, wanita perlu bijak dalam menganalisis dan mentafsir sebelum mengapliksikan etika pemakaian Islam yang betul agar tidak melanggar fitrah manusia dan syariah Islamiyyah.

\section{Rujukan}

Abdul Kareem Zaidan. (1993). al-Mufassol fi Ahkam al-Mar'ah wa al-Bayt al-Muslim fi Syariat al-Islamiyyah (1 ed.) 3, Muassah al-Risalah. Abdul Kareem Zaidan. (2000). al-Mufassol fi Ahkam al-mar'ah wal-bait al-Muslim fi Syariah al-Islamiyah (3 ed.) Beirut: Muassah al-Risalah.

Abdullah, A. (2009). Study: Men Objectify Scantily Clad Women. Health \& Science. Retrieved from OnIslam.net website: http://www.onislam.net/english/health-andscience/faith-and-the-sciences/439279.html

Abdullah, A. (2009). Study: Men Objectify Scantily Clad Women. Health \& Science. Retrieved from OnIslam.net website: http://www.onislam.net/english/health-andscience/faith-and-the-sciences/439279.html

Abu Daud, Sulaymān ibn al-Ash 'ath al-Azdi as-Sijistani. (2003). Sunan Abi Dāud (2 ed.). Riyadh: Maktabah al-Ma'ārif li al-Nashar wa al-Tauzi'.

Abu Maryam Majdi Fathi Al-Sayed. (t.thn). Taqwa: The Provision of Believers. London: Al-Firdous Ltd.

Ahmad bin Hanbal. (2001). Musnad Ahmad bin Hanbal. Beirut: Muassasah al-Risālah.

Al-Albani, Muhammad Nasiruddin. (1994). Jilbab al-Mar'ah al-Muslimah fi al-Kitab wa Sunnah. Kaherah: Maktabah al-Islamiyyah

Al-Alusi, Abū al-Thanā' Shihāb ad-Dīn Sayyid Maḥmūd ibn 'Abd Allāh al-Ḥusayn̄̄ al-Ālūsī al-Baghdādī. (1994). Ruh al-Ma'ani fi Tafseer al-Quran al-'Azim wa alSab al-Mathan. 9, Beirut: Dar al-Kutub al-Ilmiyyah.

Al-Bukhari, Muhammad ibn Isma`il al-Bukhari al-Jư fi. (2002). al-Jāmi' al-Sohih. Beirut: Dār Tūq al-Najāh.

Al-Ghazali, Abū Ḥāmid Muḥammad ibn Muḥammad, (2005). Ihya' 'Ulum al-Din. 3, Beirut: Dar al-Ma'rifah.

Al-Nasai', Ahmad ibn Shu ayb ibn Al̄̄ ibn Sīnān Abū 'Abd ar-Rahmān (1986). al-Mujtaba min al-Sunan. Halab: Maktab al-Matbu'ah al-Islamiyah.

Al-Nawawi, Abu Zakaria Muhiy ad-Din Yahya Ibn Sharaf al-Nawawi. (1972). al-Minhaj Syrhu Sohih Muslim bin al-Hujjaj (2 ed.). Beirut: Dar Ihya' al-Turath alArabiy.

Al-Syaukani, Muhammad bin Ali bin Muhammad bin Abdullah. (1900). Naylul al-Authar Syarh Muntaqa al-Akhbar min Ahadith Saiyyidul al-Akhyar . 2, Qaherah: Maktabah Dar Turath.

Al-Tirmizi, Abū 'Īsá Muhammad ibn 'Īsá as-Sulamī aḍ-Darīr al-Būghī. (1997). Sunan al-Tirmidhi. Riyadh: Maktbah al-Ma'ārif Li al-Nashar wa al-Tauzi'.

Al-Tobari, Abu Ja'far Muhammad ibn Jarir. (2000). Jāmi' al-Bayān fi Ta'wil al-Qurān. Beirut: Muassasah al-Risālah.

Andrew J, E., Maier, Markus A., Moller, Arlen C., Friedman, Ron, Meinhardt, Jorg. (2007). Color and Psychological Functioning: The Effect of Red on Performance Attainment. Journal of Experimental Psychology: General, 136 (1), 154-168.

Bernard Jensen. (1993). Foods That Heal: A Guide To Understanding and Using The Healing Powers of Natural Foods. United States of America: Paragon Press, Honesdale, pA.

Burns, K. K. (2000). The Science Behind the Veil. Retrieved 30/4/2014, from http://www.onislam.net/english/health-and-science/faith-and-the-sciences/442410.html

Elliot, A. J. N., Daniela (2008). Romantic Red: Red Enhances Men's Attraction to Women. Journal of Personality and Social Psychology, 95(5), $1150-1164$.

Grammer, K., Renninger, L., \& Fischer, B. (2004). Disco Clothing, Female Sexual Motivation, And Relationship Status: Is She Dressed to Impress? Journal of Sex Research, 41(1), 66-74.

Ibn Taimiyyah, Taqî ad-Dîn Ahmad. (2005). Majmu' Fatawa (3 ed.) 22, Dar Wafa'.

Ibnu Kathir, Abū l-Fidā' Ismā 'ìl ibn 'Umar ibn Kațīr. (1999). Tafsir al-Qurān al-'Adzim. Beirut: Dār Toybah li al-Nashar wa al-Tauzi'.

Ibrahim, A. A. H., Ali,. (2014). The Psycho-Social Aspect of Indecent Dressing: Influence of Gender, Dress Pattern and Physical Attractiveness on Sexual Harassment. Journal of Humanities and Social Science, 19(3), 14-19.

Kamil, M., Osman-Gani, AAhad, Sulaiman, Mohamed Bin Ahmad, Khaliq, . (2010). Spirituality in the Workplace: The Role of 'Taqwa' Towards the Advancement of the Contemporary Organization. Paper presented at the 8th International Conference on Tawhidic Methodology Applied to Microenterprise Development.

Malvinder S. Parmar. (2003). Hiphunggers' Tingly Thighs. Canadian Medical Association Journal, 168 (1 16-16-a), 16.

Matthew McKay, P. F. (2000). Self-Esteem (3 ed.). United State: Newharbingerpublication, inc.

Montemurro, B. G., Meghan M. (2013). How Clothes Make the Woman Immoral Impressions Given Off by Sexualized Clothing. Clothing and Textiles Research Journal, 31(3), 167-181.

Muhammad Ismail. (2009). Hijab Memelihara Kesucian Wanita muslimah (2 ed.). Johor: Pustaka Azhar.

Muslim, Muslim ibn al-Hajjāj. (1998). Șohih Muslim. Riyadh: Bayt al-Afkār al-Dauliyyah.

Rastam, A. (2002). The Rape Report: An Overview of Rape in Malaysia (2002). Kuala Lumpur: AWAM, Strategic Info Research Development (SIRD).

Ravi Mehta, R. J. Z. (2009). Blue or Red? Exploring the Effect of Color on Cognitive Task Performances. Journal Science, 323 (5918), $1226-1229$.

Robert A.Josephs, J. K. B., Christopher G.Jacobs,. (2003). Self-Esteem Maintenance Processes: Why Low Self Esteem May Be Resistant to Change. Personality and Social Psychology Bulletin, 29(7), 920-933.

Rocine, V. G. (2015). Heads, Faces, Types, Races: Forgotten Books. 
Ruzi Suliza, H. (2006). Meniti Duri dan Ranjau: Pembikinan Gender dan Seksualiti dalam Konteks Dunia Melayu. Jurnal Antarabangsa Alam dan Tamadun Melayu, 24.

Salasiah Hanin Hamjah, E. A. R., Rosmawati Mohamad Rasit, Zainab Ismail,. (2012). Perkaitan Amalan Spiritual Dengan Pencapaian Akademik Pelajar. ASEAN Journal of Teaching and Learning in Higher Education, 4(2).

Sofiah Samsudin, M. M. (2013). Ikhtilat Dan Tabarruj: Kajian Terhadap Prinsip dan Disiplin Surah Al-Nur Dan Al-Ahzab.

Tabrani, Abu al-Qasim Sulaiman ibn Ahmad ibn Al-Tabarani. (1994). Mu'jam al-Awsot. Qaherah: Dar al-Haramain.

World Health Organisation (WHO). (2015). Health Systems. Retrieved 12/3/2015, 2015, from http://www.who.int/topics/health_systems/e

Yusuf al-Qaradawi. (1978). Halal dan Haram dalam Islam. t. t: al-Ittihad al-Islami al-a'lami lil munazhomat al-Tolabiyah 